\title{
Transformation of Air Quality over a Coastal Tropical Station Chennai during COVID-19 Lockdown in India
}

Special Issue:

Special Issue on COVID-19 Aerosol Drivers, Impacts and Mitigation (XII)

\section{OPEN ACCESS}

Received: May 15, 2020

Revised: June 6, 2020

Accepted: December 25, 2020

${ }^{*}$ Corresponding Author:

tyagib@nitrkl.ac.in

\section{Publisher:}

Taiwan Association for Aerosol Research

ISSN: $1680-8584$ print

ISSN: 2071-1409 online

\section{(c) Copyright: The Author(s)} This is an open access article distributed under the terms of the Creative Commons Attribution License (CC BY 4.0), which permits unrestricted use, distribution, and reproduction in any medium, provided the original author and source are cited.

\author{
Jyotsna Singh ${ }^{1}$, Bhishma Tyagi ${ }^{2 *}$ \\ ${ }^{1}$ Shanti Raj Bhawan, Paramhans Nagar, Kandwa, Varanasi, India \\ ${ }^{2}$ Department of Earth and Atmospheric Sciences, National Institute of Technology Rourkela, \\ Rourkela, India
}

\section{ABSTRACT}

To prevent the spread of COVID-19, Government of India imposed strict lockdown in the country from 24 March-31 May 2020, which allows the environment to revive with reduced emissions. The present work analyses the $\mathrm{PM}_{2.5}, \mathrm{NO}_{2}, \mathrm{O}_{3}, \mathrm{CO}$ and $\mathrm{SO}_{2}$ along with meteorological parameters (humidity, temperature and wind speed) at a tropical coastal station Chennai for March-May 2019 and 2020 at five locations: Alandur Bus depot, Velachery, Manali, Teynampet and U.S. Embassy Chennai. Chennai is a megacity of southern India and the state capital of Tamil Nadu, one of the worst affected states due to COVID-19. Though overall $\mathrm{PM}_{2.5}$ values decreased for the lockdown (ranging from 32-187\%), weekly analysis shows the variation in reduction/increase. $\mathrm{SO}_{2}$ and $\mathrm{O}_{3}$ values were found increasing for two sites: Teynampet ( $40 \%$ in $\mathrm{SO}_{2}$ and $\sim 48 \%$ in $\mathrm{O}_{3}$ ) and Velachery $\left(\sim 2 \%\right.$ in $\mathrm{SO}_{2}$ and $\sim 5 \%$ in $\left.\mathrm{O}_{3}\right)$, but decreasing for Alandur $\left(\sim 30 \%\right.$ in $\mathrm{SO}_{2}$ and $\sim 50 \%$ in $\mathrm{O}_{3}$ ) and Manali ( 247\% in $\left.\mathrm{SO}_{2}\right)$. $\mathrm{NO}_{x}$ and $\mathrm{CO}$ were reduced during the lockdown ( 47-125\%) for all the sites. The source regions examined by concentration weighted trajectory analysis were found to change for transporting pollution to the site. The analysis shows there are local scale variations in the air pollution for the city during COVID-19 lockdown.

Keywords: COVID-19, CWT analysis, Particulate matter, Nitrogen dioxide, Sulphur dioxide

\section{INTRODUCTION}

Novel Coronavirus or COVID-19, the greatest pandemic of the century (WHO, 2020) poses unprecedented situations for human survival in the world. Since its declaration to a pandemic and public health emergency of international concern by World Health Organisation (WHO) on January 30, 2020 (WHO, 2020); several countries put strict restrictions on the movement of people to stop spreading of COVID-19 (e.g., Bao and Zheng, 2020; Collivignarelli et al., 2020; Dantas et al., 2020; Navinya et al., 2020). On March 24, 2020, Government of India announced its first lockdown, which was followed by various stages till May 31, 2020, countrywide (https://www.mygov.in/covid-19). The lockdown affects human life in multiple ways, though the environment receives mostly positive improvements (Arora et al., 2020; Bherwani et al., 2020).

Several studies reported the change in the environment during COVID-19 and spread of COVID19 correlation with meteorology and pollution (e.g., Ahmadi et al., 2020; Arora et al., 2020; Bashir et al., 2020; Nakada and Urban, 2020; Sicard et al., 2020), and on the future planning of restrictions to keep the better environment (Paital, 2020). Muhammed et al. (2020) reported a decrease of $20-30 \%$ in $\mathrm{NO}_{2}$ concentrations over China, Europe, Italy, France, Spain and USA during COVID-19 period using Aura and Senitel-5P datasets. Though some studies reported the definite relation between meteorology and COVID-19 (Ahmadi et al., 2020; Sahin et al., 2020), these relations were not uniformly valid. Shahzad et al. (2020) pointed out that the spread of the virus may be influenced by various other factors and hence not explicitly showing any clear 
correlation with weather parameters in general. It has also been argued that the more polluted regions had higher risks of spreading of COVID-19 (Bontempi, 2020; Conticini et al., 2020; Fattorini and Regoli, 2020).

In such a situation, understanding the emission patterns of a megacity is far more important for better planning to reduce the future emissions. India has a high population density in megacities, and has reported significant modelling studies for control/projected emissions (e.g., Ghude et al., 2013; Sahu et al., 2017; Guttikunda and Jawahar, 2018). For the present study, we have studied the air pollution variation during COVID-19 lockdown for Chennai, a coastal Indian megacity. Few reported studies dealing with multicity analysis, are highlighting the reduction in pollution during the lockdown period of COVID-19 over Chennai. Kumar et al. (2020) studied fine particulate matter using satellite derived Aerosol Optical Depths (AOD) and in-situ observed hourly data by U.S. Embassy over five megacities of India (Delhi, Kolkata, Mumbai, Chennai and Hyderabad) during COVID-19 lockdown. They found that aerosol loading decreased $29 \%$ over Chennai with considerable improvements in premature deaths. Jain and Sharma (2020) also took five megacities (Delhi, Kolkata, Mumbai, Chennai and Bangalore), but using the in-situ observations. They take more than one station at each of the city, and Chennai had four reporting stations. The study reported a $14 \%$ reduction in $\mathrm{PM}_{2.5}$ and $30 \%$ reduction in $\mathrm{NO}_{2}$, a $25 \%$ reduction in $\mathrm{CO}$ and a $3 \%$ rise in $\mathrm{O}_{3}$ during the lockdown phase. Arshad et al. (2020) attempted AOD and $\mathrm{NO}_{2}$ variations during COVID-19 lockdown phase using satellite datasets over major cities of India and Pakistan. The study reported a reduction of $32-42 \%$ in $\mathrm{NO}_{2}$ and $\sim 45 \%$ reduction in AOD over the entire Indo-Pak region.

Sharma et al. (2020) focused on pollutants variation of twenty big cities of India including Chennai for analysis pre and during lockdown phases of COVID-19 and the results were supporting the earlier findings of reduced $\mathrm{PM}_{2.5}, \mathrm{PM}_{10}, \mathrm{CO}$ and $\mathrm{NO}_{2}$, and increased $\mathrm{O}_{3}$ concentration during lockdown period. Navinya et al. (2020) reported a reduction of $30.2 \%$ in $\mathrm{PM}_{2.5}, 69.2 \%$ in $\mathrm{SO}_{2}$, $36.30 \%$ reduction in $\mathrm{NO}_{2}, 23.7 \%$ reduction in $\mathrm{CO}$ during lockdown phase over Chennai. Laxmipriya and Narayanan (2020) measured $\mathrm{PM}_{2.5}$ and $\mathrm{PM}_{10}$ at five sites in Chennai using the indigenous instrument, and supported the findings of massive reductions by other researchers. Arumugam and Rajathi (2020) used $\mathrm{PM}_{2.5}, \mathrm{PM}_{10}, \mathrm{CO}, \mathrm{NO}_{2}, \mathrm{SO}_{2}$ and $\mathrm{O}_{3}$ over Chennai gave a descriptive statistical analysis of reductions in these pollutants with ANOVA fitting to variations.

Though various studies reported a reduction in pollutants and increase in $\mathrm{O}_{3}$ during COVID-19 lockdown, the detail about site to site variations have not been reported in these studies. The microscale feature may impact the local pollution values and the variation reported as an average values (including all the sites) may miss out the detail of an individual site variation. The present study will attempt to analyse the pollution change of five criterion pollutants (i.e., $\mathrm{PM}_{2.5}, \mathrm{NO}_{x}, \mathrm{O}_{3}$, $\mathrm{CO}$ and $\mathrm{SO}_{2}$ ) during the COVID-19 lockdown at five different sites in the city: Teynampet, Alandi, Velachery, Manali and U.S. Embassy. To find the difference in values, the previous year data (2019) will be compared with the 2020 data. The changing pollution levels may also be associated with changing source patterns, and hence the present study also analysed the change in source pattern for pollution during COVID-19 lockdown using Concentration weighted trajectory (CWT) method based on back-trajectories obtained by lagrangian model HYSPLIT. The study attempts to understand the nature of variation of reduced/changed levels of pollutants during COVID-19 lockdown. The study is also crucial to understand the baseline emissions, as Chennai is the Indian megacity with lower pollution levels, and the state capital of Tamil Nadu, one of the worst COVID19 hit regions in India.

\subsection{Study Sites, Data Used and Methodology}

The study region is Chennai, a tropical coastal station situated the coast of Bay of Bengal. Chennai is the state capital of Tamil Nadu and one of the densely populated megacities of India with a population of 4,646,732 (Census, 2011). The sites in Chennai are: Teynampet, U.S. Embassy, Alandur bus depot, Manali and Velachery. The five sites are covering main populated areas of Chennai and are $\sim 23 \mathrm{~km}$ away spatially from north to south. The locations of all five sites are depicted on Google earth imagery in Fig. 1. Teynampet is the monitoring station of world air quality index (WAQI) project (https://aqicn.org/products/gaia/), located in the commercial localities in the city of Chennai. U.S. Embassy is also located in the Teynampet area, though is $<1 \mathrm{~km}$ spatial distance from the WAQI station. The CPCB monitoring stations are: Velachery, a 


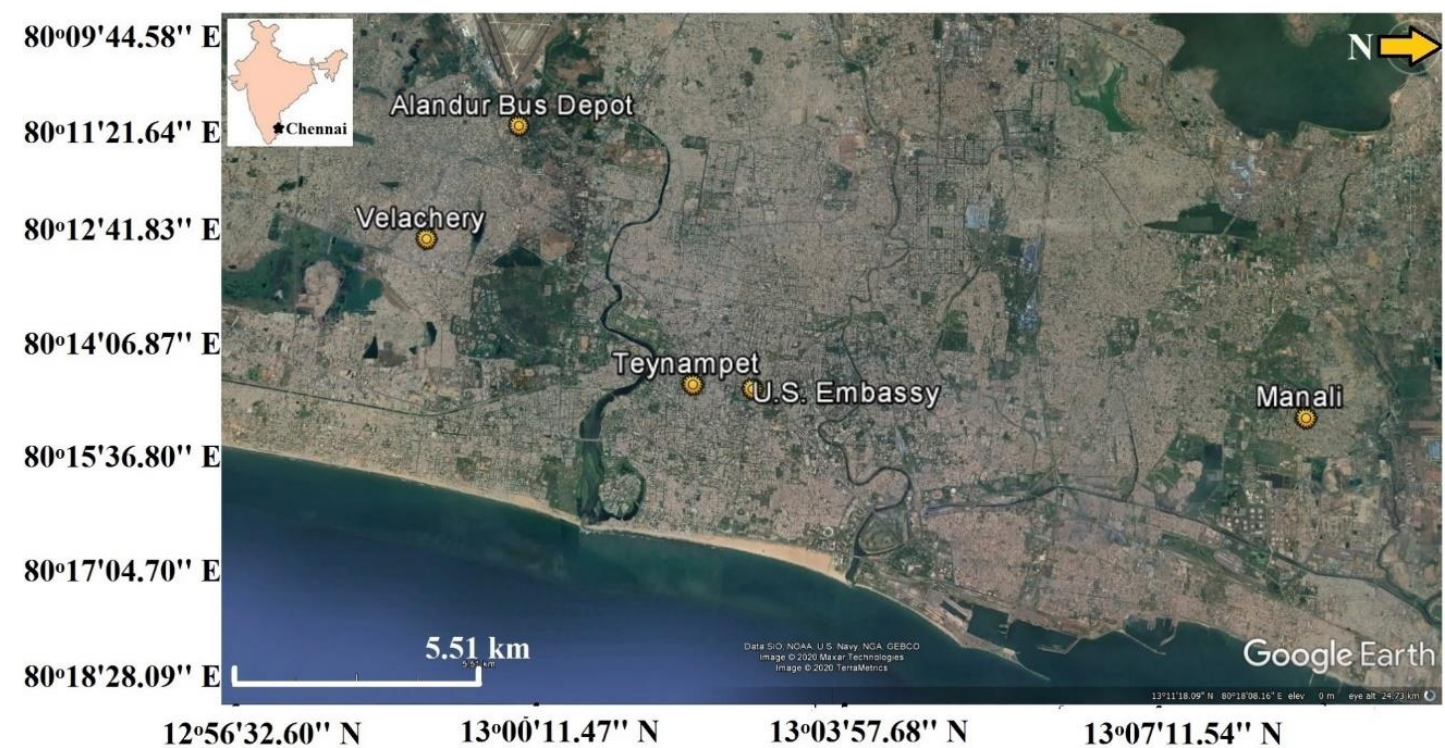

Fig. 1. Site locations for the present study using Google earth imagery. The location of Chennai on the map of India is denoted by a black star in the inset.

residential cum commercial area in South Chennai; Alandur, an urbanised zone of Chennai corporation, in Guindy division and Manali, an Industrial cum residential area.

The data for the present study has been adopted from different sources. The data has been adopted for the pre-lockdown (1-23 March 2020), lockdown period (24 March-31 May 2020) and same period of 2019 . The air quality data at Teynampet $\left(13.05^{\circ} \mathrm{N}, 80.25^{\circ} \mathrm{E}\right)$ has been taken from world air quality index (https://waqi.info/aqicn.org), for daily average values of fine Particulate Matter $\left(\mathrm{PM}_{2.5}\right)$, Nitrogen di oxide $\left(\mathrm{NO}_{2}\right)$, surface ozone $\left(\mathrm{O}_{3}\right)$, Sulfur dioxide $\left(\mathrm{SO}_{2}\right)$ and Carbon Monoxide ( $\mathrm{CO}$ ) concentrations and meteorological parameters (humidity, temperature and wind speed). For $\mathrm{PM}_{2.5}, \mathrm{NO}_{x}, \mathrm{O}_{3}, \mathrm{SO}_{2}$ and $\mathrm{CO}$; we have also taken data from the Central Pollution Control Board (CPCB) at Alandur bus depot, Velachery and Manali. At Manali, $\mathrm{O}_{3}$ observations were absent for the period of our analysis (https://cpcb.nic.in). We have also obtained $\mathrm{PM}_{2.5}$ data at Consulate General of the United States, Chennai $\left(13.03^{\circ} \mathrm{N}, 80.15^{\circ} \mathrm{E}\right)$ from AirNow website (www.airnow.gov). The units for $\mathrm{PM}_{2.5}$ are $\mu \mathrm{g} \mathrm{m}^{-3}$ and parts per billion volume (ppbv) for $\mathrm{NO}_{\mathrm{x}}$, $\mathrm{O}_{3}, \mathrm{SO}_{2}$ and $\mathrm{CO}$. The spatial distance between Teynampet and Consulate General of the United States, Chennai is $<1 \mathrm{~km}$, though the pollution statistics and population density differ at both the places, hence will allow understanding microscale differences. Details about COVID-19 lockdown dates are obtained from the Government of India website (http://www.mygov.in).

Before starting the analysis, all the datasets have been quality checked by these two criterions: (a) removal of all zero, negative and invalid data points by the manual inspection of the dataset, (b) outlier detection to clean the obtained dataset (Kumar et al., 2020). The data has been analysed to understand the lockdown effect on pollution and compared with the same period of 2019 . To get the percentage variation in various pollutants, we calculated the percentage change in values of 2020 from that of 2019 as

Percentage Change of Pollutant in $2020=\frac{(\text { Values in } 2020-\text { Value in 2019) }}{\text { Value in } 2019} \times 100$

The change in pollution parameters for the lockdown period of 2020 and similar period of 2019 has been analysed with 1\%-99\% data limit, 25, 50 and $75 \%$ quartiles and mean values of the data. For understanding the weekly progression of pollution change, we have also calculated weekly variations in percentage change from 1 March-31 May 2020 for Teynampet and U.S. Embassy sites.

We employed back trajectory analysis using National Oceanic and Atmospheric Administration's Lagrangian model: HYSPLIT (Hybrid Single-Particle Lagrangian Integrated Trajectories). The HYSPLIT 
derived two days ( $48 \mathrm{~h}$ ) isentropic back trajectories at every three hours using GDAS (Global Data Assimilation System) $1^{\circ} \times 1^{\circ}$ data sets (Draxler and Hess, 1998) has been used for the present work. Concentration weighted trajectory (CWT) analysis has been employed based on two-day back trajectories. The CWT method allows understanding the geographical overview of emission source areas, contributing the transported pollutants to study region, i.e., Chennai in the present case. The method calculates the weighted concentration of each grid cell, combined with measured average concentrations of the pollutant at the site and corresponding trajectories crossing each grid cell. The details of CWT methodology can be adopted from Dimitriou (2015). The figures used in the present work have been prepared using originlab (www.originlab.com) and Matlab (www.mathworks.com) software, respectively.

\section{RESULTS}

\subsection{Variation of Meteorological Parameters}

The daily average air temperature, relative humidity $(\mathrm{RH})$ and wind speed data at Teynampet, Chennai has been analysed for lockdown period (24 March-31 May 2020) and the similar period of 2019, presented in Fig. 2. The RH values of 2020 were $10 \%$ higher to 2019, till 10 May 2020, after which both years values are fluctuating and coming to a similar range (Fig. 2(a)). The air temperatures were low during the lockdown phase (Fig. 2(b)), with $\sim 2^{\circ} \mathrm{C}$ difference until 10 May 2020. As the temperature and $\mathrm{RH}$ variations at the surface are correlated (Sahu et al., 2019), the increase in humidity and decrease in air temperature in the present case is justifying their nature of correlation. Though wind speed is fluctuating, there is a clear increase in 2020 wind speed throughout the lockdown period compare to the previous year's value (Fig. 2(c)). The high wind speed can reduce the pollution load over any area by transporting it to longer distances (Oke et al., 2017).

The results are displaying that basic meteorological variables were not behaving the same as that of the previous year during the lockdown period, and this can impact the pollution dispersion over the region. Though one cannot relate one to one the difference of the meteorological variables to changed pollution during the lockdown period, it is to keep in to account that not only imposing restrictions on vehicular and industrial emissions, natural forcings were also different for transportation and dispersion of pollutants over the region during 24 March-31 May 2020.

\subsection{Change in Air Pollutants during COVID-19 Lockdown}

Pollution change during lockdown is widely reported globally, with reduced values in various

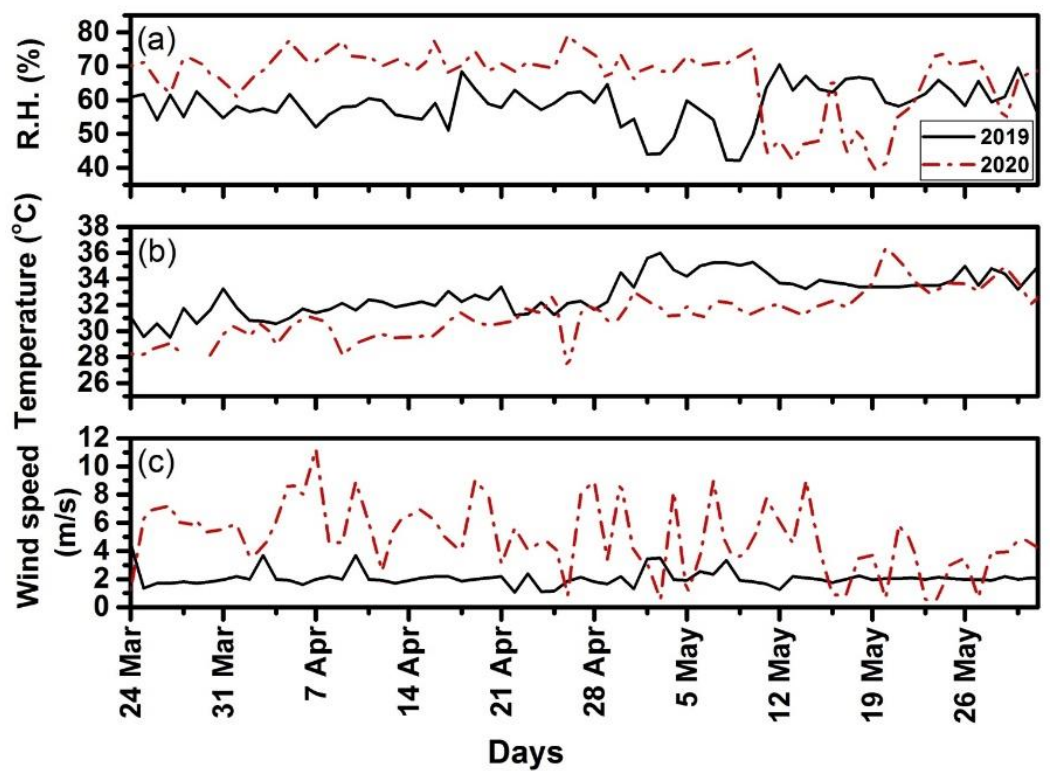

Fig. 2. Variation of meteorological parameters (a) Relative Humidity (\%), (b) Air Temperature (in $\left.{ }^{\circ} \mathrm{C}\right)$ and (c) Wind Speed $\left(\mathrm{m} \mathrm{s}^{-1}\right)$ during lockdown period of 2020, and similar period of 2019. 
components (Bherwani et al., 2020; Bontempi, 2020). Over Chennai also, there are various reported studies of reduced pollution during lockdown period and some of them are documented in Table 1 with sites, type of data used for analysis and key findings. Though all of these studies are having a prime focus on aerosols, some of them also reported $\mathrm{NO}_{2}, \mathrm{CO}, \mathrm{SO}_{2}$ reduction and surface ozone increase during the lockdown period. However, as most of them were taking Chennai as one of the many sites, the results were calculated for the overall period as a single value by either subtracting from the previous year or from the pre-lockdown phase. Table 2 suggests that the variations are different by various studies due to different sampling sites, the difference in the period to compare, different sampling instruments/methods and different satellite data acquisitions. The reductions reported for $\mathrm{PM}_{2.5}$ are in the range $5.4-97 \%, 29-45 \%$ for $\mathrm{AOD}, 18-42 \%$ for $\mathrm{NO}_{2}, 25.96-69.2 \%$ for $\mathrm{SO}_{2}, 18-25 \%$ for $\mathrm{CO}$ and increase of $3-47 \%$ for $\mathrm{O}_{3}$. Though as these values are based on average of different sites, the variations for different sites may show a different picture compare to overall average values of Chennai.

The present study attempts to see the change in pollutants during COVID-19 lockdown (from baseline of 2019), to understand the environmental change with lockdown restrictions. Fig. 3 shows the differences in values of pollutants during the lockdown period of 2020 and the same period of 2019. The figure plots 1-99\% data limit; 25, 50 and 75\% quartiles and mean values of the total period. For $\mathrm{SO}_{2}$ (Fig. 3(a)), the values during COVID-19 lockdown are higher to the previous year at Teynampet and Velachery, however, the Alandur and Manali are showing reduction during the lockdown period. For $\mathrm{NO}_{x}$ (Fig. 3(b)) and $\mathrm{PM}_{2.5}$ (Fig. 3(c)), the values during the lockdown are less than the previous year for all the sites. As reported by various studies, there is an increase

Table 1. Change in various atmospheric pollutants during the COVID-19 lockdown over Chennai as reported by various researchers.

\begin{tabular}{|c|c|c|c|}
\hline S. No. & Study & Study Site(s) [type of data] & Key Findings \\
\hline 1 & Kumar et al. (2020) & U.S. Embassy [in-situ and satellite] & $\begin{array}{l}32 \% \text { reduction in } \mathrm{PM}_{2.5} \text { and } 29 \% \text { reduction in } \mathrm{AOD} \\
\text { loading }\end{array}$ \\
\hline 2 & $\begin{array}{l}\text { Jain and Sharma } \\
\text { (2020) }\end{array}$ & $\begin{array}{l}\text { Alandur Bus depot, Manali, Manali } \\
\text { village, Velachery residential area } \\
\text { [in-situ] }\end{array}$ & $\begin{array}{l}14 \% \text { reduction in } \mathrm{PM}_{2.5}, 30 \% \text { reduction in } \mathrm{NO}_{2}, 25 \% \\
\text { reduction in } \mathrm{CO} \text { and a } 3 \% \text { rise in } \mathrm{O}_{3}\end{array}$ \\
\hline 3 & Arshad et al. (2020) & Total Indo-Pak region [satellite] & $32-42 \%$ in $\mathrm{NO}_{2}$ and $\sim 45 \%$ reduction in $\mathrm{AOD}$ \\
\hline 4 & Sharma et al. (2020) & $\begin{array}{l}\text { CPCB stations (name not } \\
\text { mentioned) [in-situ] }\end{array}$ & $\begin{array}{l}\text { 31, } 10 \text {, and } 18 \% \text { reduction in } \mathrm{PM}_{2.5}, \mathrm{CO} \text {, and } \mathrm{NO}_{2} \text { in } \\
\text { general over all stations }\end{array}$ \\
\hline 5 & Navinya et al. (2020) & Manali [in-situ] & $\begin{array}{l}30.2 \% \text { reduction in } \mathrm{PM}_{2.5}, 69.2 \% \text { reduction in } \mathrm{SO}_{2} \text {, } \\
36.30 \% \text { reduction in } \mathrm{NO}_{2}, 23.7 \% \text { reduction in } \mathrm{CO}\end{array}$ \\
\hline 6 & $\begin{array}{l}\text { Laxmipriya and } \\
\text { Narayanan (2020) }\end{array}$ & $\begin{array}{l}\text { Ambattur, Maduravayol, Porur, } \\
\text { Valasaravakkam, Koyembedu and } \\
\text { Annanagar [in-situ] }\end{array}$ & $80-97 \%$ reduction in $\mathrm{PM}_{2.5}$ and $\mathrm{PM}_{10}$ \\
\hline 7 & Zhang et al. (2020) & Chennai [satellite] & $\begin{array}{r}30.62 \% \text { reduction in } \mathrm{NO}_{2}, 38.19 \% \text { reduction in } \mathrm{PM}_{2.5} \\
25.96 \% \text { reduction in } \mathrm{SO}_{2} \text { and } 47.13 \% \text { increase in } \mathrm{O}_{3}\end{array}$ \\
\hline 8 & $\begin{array}{l}\text { Singh and Chauhan } \\
\text { (2020) }\end{array}$ & U.S. Embassy [in-situ and satellite] & $5.4 \%$ reduction in $\mathrm{PM}_{2.5}$ and reduced values of $\mathrm{NO}_{2}$ \\
\hline 9 & Siddiqui et al. (2020) & Chennai [satellite] & $33 \%$ reduction in $\mathrm{NO}_{2}$ \\
\hline
\end{tabular}

Table 2. Percentage change in various pollutants for the total lockdown period (24 March-31 May) for 2020 compare to 2019 for the present study.

\begin{tabular}{llllll}
\hline Parameter & Teynampet & Velachery & Alandur & Manali & U.S. Embassy \\
\hline $\mathrm{NO}_{x}$ & -47.53 & -33.92 & -55.66 & -41.63 & - \\
$\mathrm{SO}_{2}$ & 40.47 & 71.69 & -94.36 & -71.23 & - \\
$\mathrm{O}_{3}$ & 48.01 & 5.16 & -33.37 & - & - \\
$\mathrm{CO}$ & -90.72 & -5.60 & -61.36 & -9.40 & - \\
$\mathrm{PM}_{2.5}$ & -39.73 & -65.24 & -40.37 & -42.14 & -24.23 \\
\hline
\end{tabular}

${ }^{\#} \mathrm{NO}_{2}$ value. 

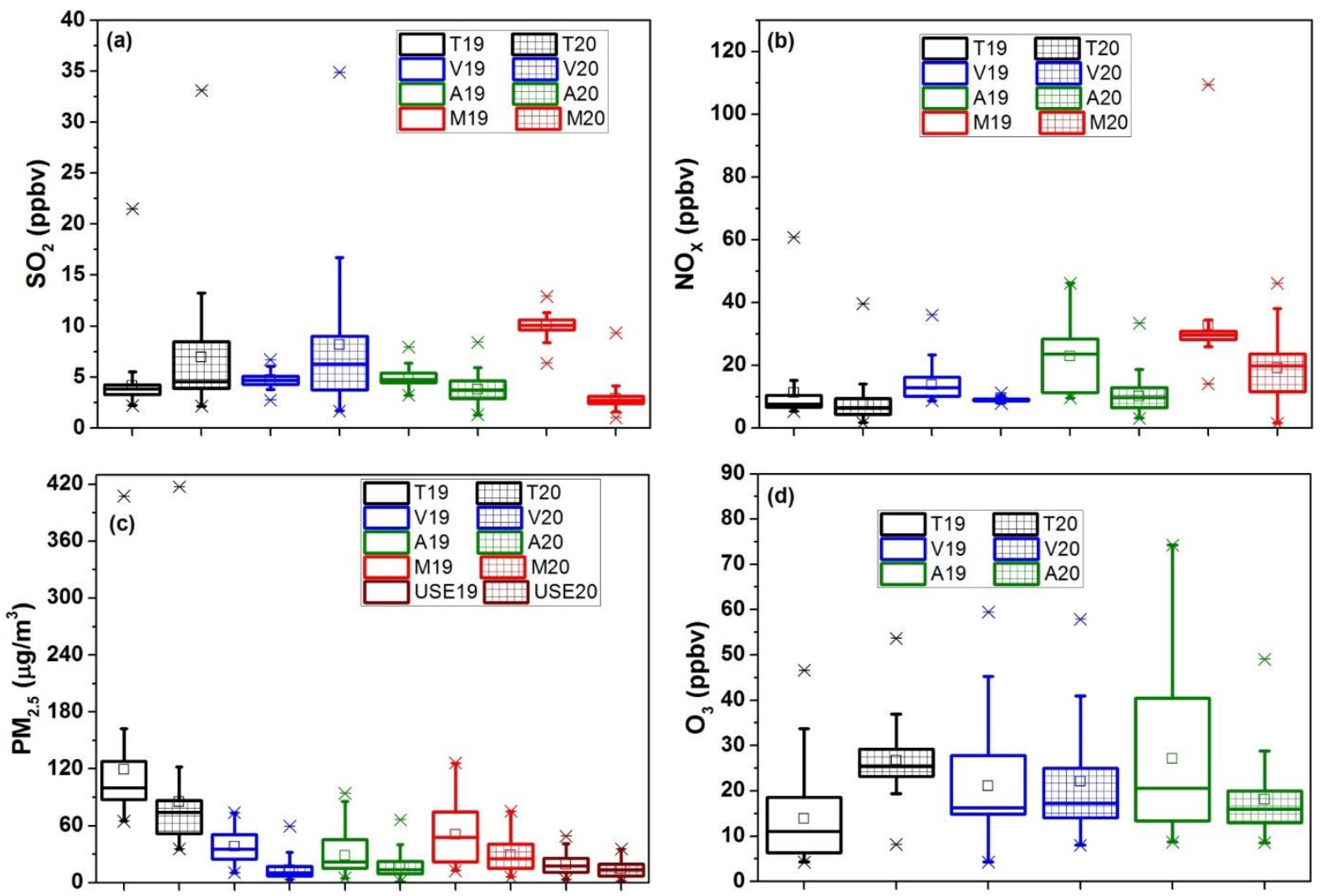

Fig. 3. Box-Whisker diagram for the (a) $\mathrm{SO}_{2}$, (b) $\mathrm{NO}_{x}$, (c) $\mathrm{PM}_{2.5}$ and (d) $\mathrm{O}_{3}$. The diagram is indicating the $1 \%$ data limit (lower $\mathrm{X}$ ), $99 \%$ data limit (upper X), 25, 50 and 75\% quartiles with lower upper extreme in the box, and mean values (square) of the total lockdown period. The legend indicates the station name and year, i.e., T: Teynampet; V: Valechery; A: Alandur; M: Manali and USE: U.S. Embassy with 19: 2019 and 20: 2020, respectively.

in $\mathrm{O}_{3}$ values at Teynampet and Velachery; however, Alandur shows a reduction in $\mathrm{O}_{3}$ during the lockdown period. We don't have data for $\mathrm{O}_{3}$ at Manali, and only $\mathrm{PM}_{2.5}$ observations were available at U.S. Embassy. Though $\mathrm{NO}_{x}$ and $\mathrm{CO}$ were reduced during the lockdown at Alandur, the reduced $\mathrm{O}_{3}$ values may be a result of transported $\mathrm{O}_{3}$ reduction at Alandur; compare to previous year. It is reported at various sites in India that transported $\mathrm{O}_{3}$ are able to maintain higher concentrations at a site even with less local production locally (Sinha et al., 2016). However, the microscale analysis was not made for the present study due to unavailability of such observations, and we may not be able to confirm the exact reasons of reduced $\mathrm{O}_{3}$ during the lockdown period.

To quantify the exact differences between the lockdown period and previous year values, we have computed the percentage change (given in Table 2). The values are in the range of previously reported studies (Table 1 ), though it is clear that at each site, the variation differs. The highest reduction in $\mathrm{PM}_{2.5}$ occurs at Velachery $(65.24 \%)$, whereas the lowest reduction happened at the U.S. Embassy (24.23\%). Velachery also showed the highest increase in $\mathrm{SO}_{2}$ values (71.69\%) and the least increase in $\mathrm{CO}(5.60 \%)$. Alandur, on the other hand, showed reduced values of all the pollutants, including $\mathrm{O}_{3}$ also. Teynampet also showed increased $\mathrm{SO}_{2}$ values $(40.47 \%)$ during the lockdown. The $\mathrm{O}_{3}$ values increased by $48.01 \%$ at Teynampet during the lockdown. Though the $\mathrm{O}_{3}$ values were not available at Manali, other pollutants reduced significantly at Manali during the lockdown. The difference in concentrations can be attributed to local emission patterns mainly, as the sites are nearby in the spatial distance, but have a different population density, locality and architectural planning and emission patterns.

To further understand the day to day variations of pollutants during the lockdown period and comparative period from previous year, we have analysed the daily values at Teynampet, as it is the commercial area and is centrally located among the chosen five sites in Chennai for the present study. Fig. 4 represents the daily variation of $\mathrm{PM}_{2.5}$ and $\mathrm{SO}_{2}$ from 1 March-31 May 2020 and 2019 at Teynampet. While analyzing $\mathrm{PM}_{2.5}$ variation, we can see that though the levels of 
5 (a)

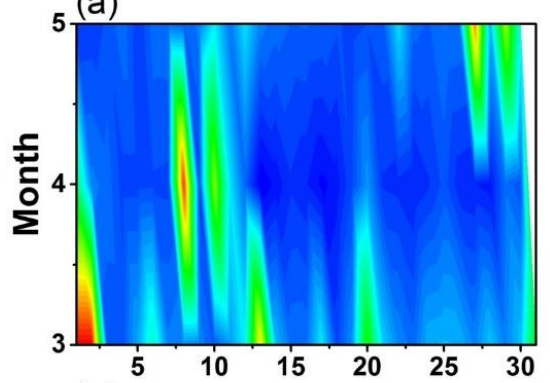

5

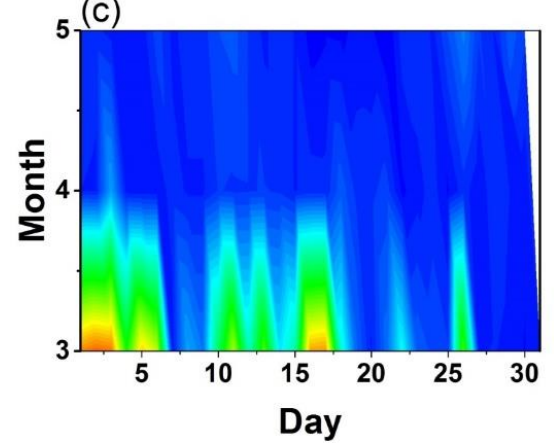

5 (b)
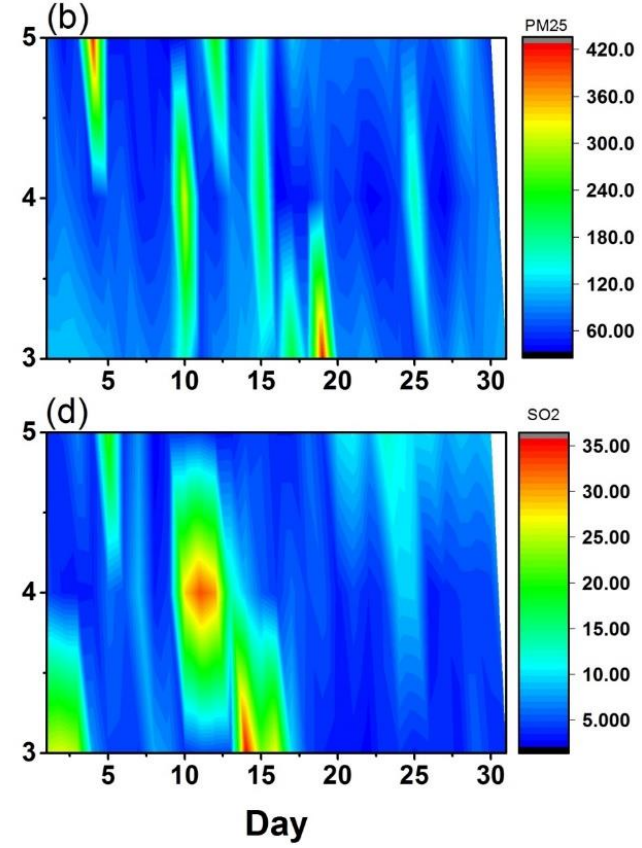

Fig. 4. Variation in $\mathrm{PM}_{2.5}\left(\mu \mathrm{g} \mathrm{m}^{-3}\right.$ ) and $\mathrm{SO}_{2}$ (ppmv) for 1 March-31 May of 2020 and 2019. The top row shows variation in $\mathrm{PM}_{2.5}((\mathrm{a})$ and $(\mathrm{b}))$, and the bottom row shows variations in $\mathrm{SO}_{2}((\mathrm{c})$ and (d)). The left column is representing 2019 and the right column is 2020.

pollution are generally in the range of $60-100 \mu \mathrm{g} \mathrm{m}^{-3}$ for most of the days, there were some episodic events observed in 2019 (Fig. 4(a)) as well as in 2020 (Fig. 4(b)), where the values were reaching up to $\geq 400 \mu \mathrm{g} \mathrm{m} \mathrm{m}^{-3}$ in a daily average. Such high pollution events were observed frequently in 2020 during pre-lockdown (i.e., 1-23 March), however, during lockdown period, such cases were comparatively less than 2019. The observation articulates that episodic pollutions events were active even during the lockdown period, changing the average of weekly/monthly data quickly with high values.

As the lockdown imposed strict regulations of non-movement of vehicles (except emergency services) and shutdown of industries, these higher values of $\mathrm{PM}_{2.5}$ are not results from vehicular of industrial emissions. However, thermal power plants burning coal may not be ruled out for such events. There are more than seven major thermal power plants in the state of Tamilnadu with North Chennai thermal power station of $1830 \mathrm{MW}$ capacity running right at Chennai (http://www.tangedco.gov.in/linkpdf/tnctps.pdf), which is utilizing coal for power generation. The episodic events may be results of changed dispersion due to meteorological conditions on a particular day. The $\mathrm{SO}_{2}$ variations are showing that during March 2019 (Fig. 4(c)), the values were on the higher side ( 25-35 ppmv), which substantially reduces to lower values till 31 May. However, during the lockdown period, the higher values of $\mathrm{SO}_{2}$ are observed for few days (Fig. 2(d)) compare to 2019, which again may be a result of change emission pattern and related to thermal power plants emissions. Other reason for such increase may be related to higher use of fossil fuels (coal and wood) in residential areas, producing high values (Sahu et al., 2008). However, overall changes are in the pollution limits specified by the Government of India (CPCB, 2015).

Fig. 5 represents the change in surface $\mathrm{O}_{3}, \mathrm{NO}_{2}$ and $\mathrm{CO}$ during 1 March-31 May 2019 and 2020 at Teynampet. $\mathrm{O}_{3}$ has substantially increased during 2020, especially during the lockdown period (Fig. 5(b)). The values are almost double of 2019 (Fig. 5(a)) for the same period. Though air temperature reduces in 2020 (Fig. 2(b)), this increase in $\mathrm{O}_{3}$ is a result of a decrease in $\mathrm{NO}_{2}$ and $\mathrm{CO}$ (Figs. 5(d) and 5(f)) during the lockdown period. The reduced vehicular and industrial emissions show a direct decrease in $\mathrm{NO}_{2}$ and $\mathrm{CO}$, resulting in a hike in $\mathrm{O}_{3}$ values, which was not the case in 2019 (Figs. 5(a), 5(c) and 5(e)).

The percentage change (based on Eq. (1)) for the weekly changes of all the pollutants observed at Teynampet (designated as site 1 ) and also the $\mathrm{PM}_{2.5}$ values at Consulate General of the United States (designated as site 2 ) are given in Table 3 . The reduced values (negative sign) are marked 

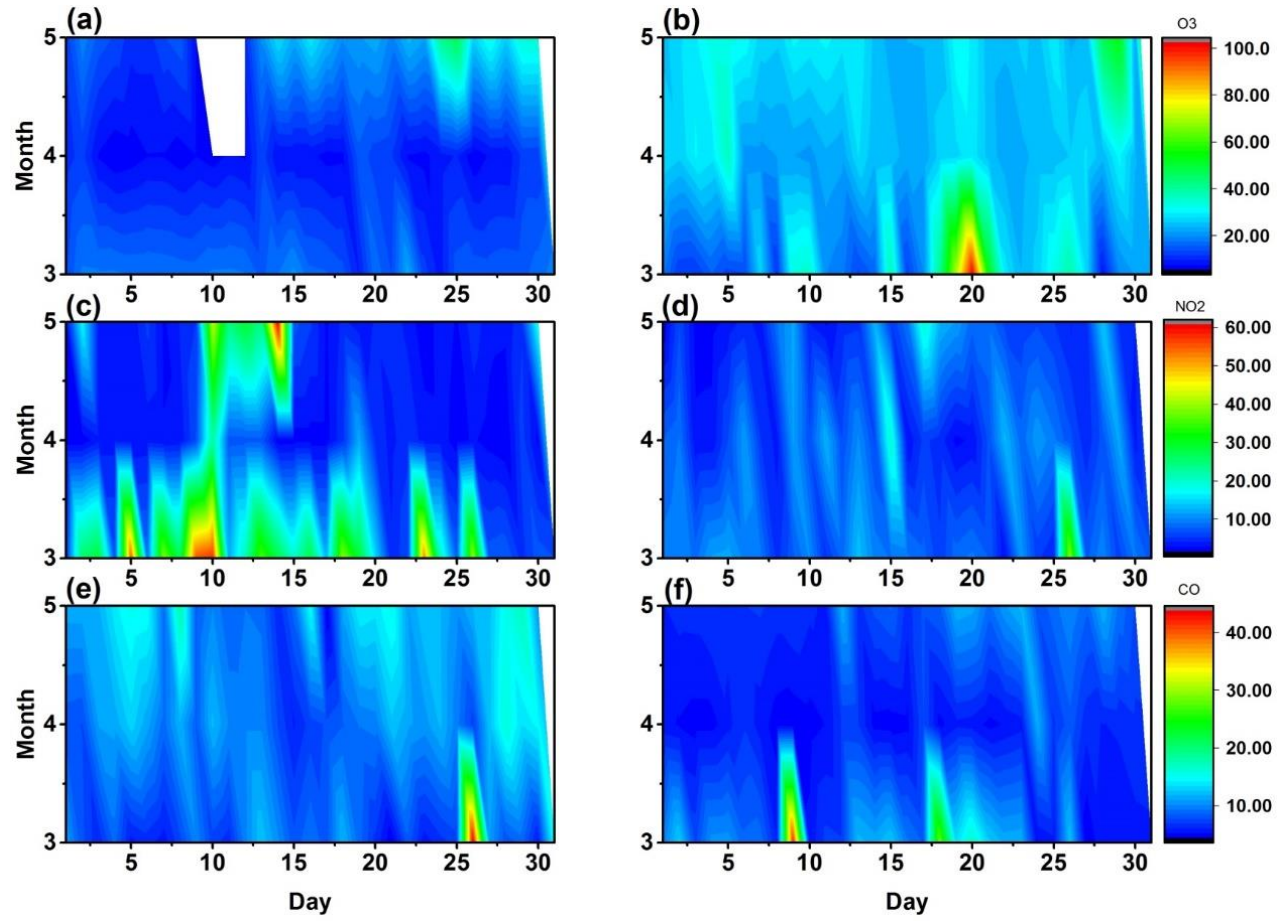

Fig. 5. Variation in $\mathrm{O}_{3}$ (ppbv), $\mathrm{NO}_{2}$ (ppbv) and $\mathrm{CO}$ (ppmv) for 1 March-31 May of 2020 and 2019. The top row shows variation in $\mathrm{O}_{3}((\mathrm{a})$ and $(\mathrm{b}))$, middle row shows variation in $\mathrm{NO}_{2}((\mathrm{c})$ and $(\mathrm{d}))$ and the bottom row shows variations in $\mathrm{CO}((\mathrm{e})$ and $(\mathrm{f}))$. The left column is representing 2019 and the right column is 2020 .

Table 3. Percentage change in various pollutants on a weekly basis for 2020 compare to 2019. Site 1 is Teynampet and Site 2 is Consulate General of the United States, Chennai.

\begin{tabular}{|c|c|c|c|c|c|c|c|}
\hline & Week of the study & Site 1: $\mathrm{PM}_{2.5}$ & Site 2: $\mathrm{PM}_{2.5}$ & Site 1: $\mathrm{SO}_{2}$ & Site $1: \mathrm{O}_{3}$ & Site 1: $\mathrm{NO}_{\mathrm{x}}$ & Site 1: CO \\
\hline \multirow{13}{*}{ 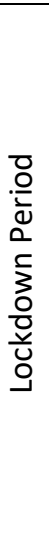 } & W1 (1-7 March) & -49.81 & 51.84 & -43.06 & -0.95 & -61.58 & 1.99 \\
\hline & W2 (8-14 March) & -35.48 & -8.53 & -31.24 & 32.63 & -76.09 & 15.82 \\
\hline & W3 (15-21 March) & 19.92 & -25.57 & -27.66 & 246.84 & -65.07 & 40.07 \\
\hline & W4 (22-28 March) & -29.40 & -1.43 & -54.26 & 97.56 & -49.53 & -45.33 \\
\hline & W5 (29 March-4 April) & -42.15 & 34.50 & 0.89 & 129.21 & -15.24 & -55.21 \\
\hline & W6 (5-11 April) & -42.50 & 26.26 & 247.28 & 324.55 & -19.74 & -58.10 \\
\hline & W7 (12-18 April) & 12.31 & 22.05 & 182.78 & 241.92 & 16.72 & -41.93 \\
\hline & W8 (19-25 April) & -37.90 & -127.20 & 24.56 & 200.51 & -19.09 & -50.25 \\
\hline & W9 (26 April-2 May) & -4.42 & -136.99 & 35.03 & 218.93 & 0.56 & -53.38 \\
\hline & W10 (3-9 May) & 7.46 & -252.54 & 93.00 & 137.62 & -50.24 & -57.23 \\
\hline & W11 (10-16 May) & -15.66 & -129.13 & -4.91 & 69.56 & -77.76 & -29.37 \\
\hline & W12 (17-23 May) & -17.33 & 21.47 & 121.57 & 18.64 & 44.19 & -33.75 \\
\hline & W13 (24-31 May) & -52.97 & -33.17 & 107.24 & -2.49 & -29.21 & -35.16 \\
\hline
\end{tabular}

with a blue colour for visual understanding. Both sites 1 and 2 are $<1 \mathrm{~km}$ spatial distance to each other; however, the range of $\mathrm{PM}_{2.5}$ they are recording is different. The difference may result due to various reasons including population density, traffic, and instrument use at two sites. However, not commenting on the nature and reason of differences in values, we want to highlight here the difference in percentage change for these two sites, representing the local impacts on measurements. For the first three weeks, during the pre-lockdown period, Site 1 is showing mostly reduced value of $\mathrm{PM}_{2.5}$, while Site $2 \mathrm{PM}_{2.5}$ values have increased. During the lockdown period, Except W7 and W10, Site 1 values of $\mathrm{PM}_{2.5}$ are always showing a reduction in 2020. Though, Site 2 experience higher $\mathrm{PM}_{2.5}$ in W5, W6, W7 and W12 and the level of PM2.5 was higher than previous year values. This difference may be explained with the fact that though most of the public transportation and 
other emissions were reduced during the lockdown, the embassy area was not that affected due to nature of work in various consulates located in that area. Increase in value signifies that emissions are constantly increasing over the Consulate area. The $\mathrm{SO}_{2}$ variations raised unexpectedly in 2020, especially during the lockdown period. Though the values of $\mathrm{SO}_{2}$ over the study area is well within threshold limits, the results are indicating residential burning of coal and wood might have increased during the lockdown period, significantly contributing to the increase (Sahu et al., 2008) producing increased values in 2020. The $\mathrm{O}_{3}$ values increase markedly in all the weeks of study during the lockdown, which is associated with reduced values of $\mathrm{NO}_{2}$ and $\mathrm{CO}$ due to restrictions on vehicular and industrial emissions.

The changed values of various pollutants during the COVID-19 lockdown period are supporting the findings of reported values from literature (Table 1). The values are not exactly matching with previous studies, due to difference in period to compare with and the averaging methods. The other reason for difference may be due to the reason that earlier studies only showed the average picture of variation for the whole period (either by taking average of in-situ observations at several sites or by satellite data), the present work is able to show the difference in location wise pollution change. Teynampet (commercial site) and U.S. Embassy (government office area) are able to show difference in the pollution reduction, though both are close by spatial distance. The other sites, which are north or south to these sites, are also able to bring the local scale differences in pollutants reduction during COVID-19 lockdown.

\subsection{Identifying Changes in Source Regions with Changed Pollution Levels}

Two days isentropic back trajectories at every three hourly intervals have been computed for 24 March-31 May 2019 and 2020 using HYSPLIT model. The back trajectories are not showing any significant differences in their number concentrations to any particular region during the lockdown period. As the pollution levels have been changed during the lockdown period, one can expect a change in the source regions as well. Identifying the source pattern will be even more challenging during the lockdown period, as the reduced pollution is not only present at the study site but also to source regions transporting pollution to study site. We have performed CWT analysis using the back trajectories and hourly $\mathrm{PM}_{2.5}$ data obtained at site 2 (US Consulate). The reason for choosing $\mathrm{PM}_{2.5}$ at site 2 is its hourly availability, providing more data points for CWT, and also the higher variability in $\mathrm{PM}_{2.5}$ data during the lockdown.

Fig. 6 is showing CWT analysis for 2019 (Fig. 6(a)) and 2020 (Fig. 6(b)) for 24 March-31 May. As we can see, the source regions for transported pollution reaching to study site for 2019 are widely spread (Fig. 6(a)) and reach to the site by crossing states of Andhra Pradesh, Telangana, Karnataka and Maharashtra. The megacity Mumbai and Pune in Maharashtra are also appearing as source region to the study area. The oceanic transport and its relative contribution to the site in 2019 are insignificant in 2019. During the COVID-19 lockdown (Fig. 6(b)), the pollution sourceapportionment pattern changed. The regions of Andhra Pradesh and Karnataka are prime source areas contributing to transported pollution. Highly populated and polluted cities of Maharashtra
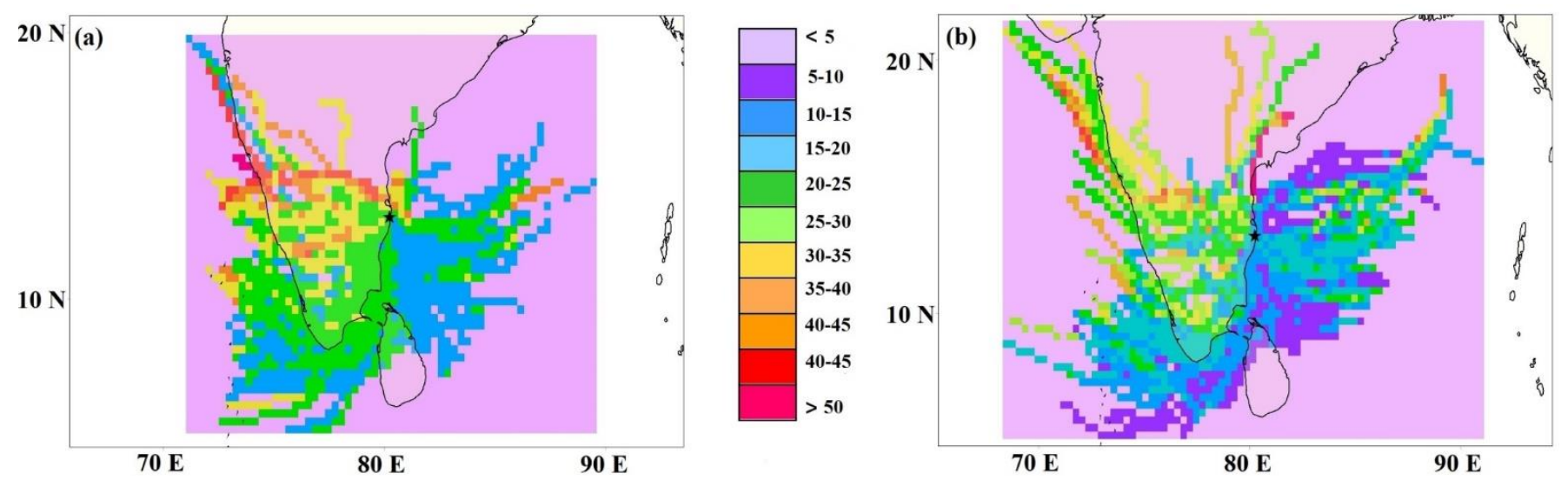

Fig. 6. Concentration weighted trajectory plot for $\mathrm{PM}_{2.5}$ using two day three hourly isentropic back trajectories for (a) 2019 and (b) 2020 . Site location is depicted by a black star in both the figures. 
and Telangana are not significantly transporting pollution to the site during the lockdown. The source apportionment results are also suggesting that the local contribution to $\mathrm{PM}_{2.5}$ is relatively small in the observed values. Another crucial finding of CWT is redistribution of oceanic component contribution. During the lockdown, oceanic transportation increases, suggesting that sea salt sprays are also significant contributing regions to Chennai pollution. As the prospect changed due to COVID-19, so as the source regions and their relative contribution to transported pollution over Chennai.

\section{SUMMARY}

The present study investigated daily pollution change during COVID-19 lockdown over Chennai. The work can be summarised in the following points:

- There is an increase in $\mathrm{RH}(\sim 10 \%)$, decrease in air temperature $\left(\sim 2^{\circ} \mathrm{C}\right)$ and increase in wind speed $\left(\sim 2 \mathrm{~m} \mathrm{~s}^{-1}\right)$ during COVID-19 lockdown over Chennai.

- The $\mathrm{SO}_{2}$ values increased at Teynampet and Velachery (40.47 and $70.69 \%$ ) but there is a reduction at Alandur and Manali (94.26 and $71.23 \%$ ).

- $\quad \mathrm{PM}_{2.5}$ values showed significant reduction at all five sites during the COVID-19 lockdown. The values reduced in a range of 24.23-65.24\%, respectively. Though the weekly analysis showed that the decrease is not at constant rate and there are weeks with higher values as well. The reason may be attributed to operational coal-powered thermal power plants in nearby regions and higher use of fossil fuel during the lockdown. There is an evident decrease in $\mathrm{NO}_{\mathrm{x}}$ and $\mathrm{CO}$ at all the sites of present study (41.63-55.66\% for $\mathrm{NO}_{\mathrm{x}}$ and $5.60-90.72 \%$ for $\left.\mathrm{CO}\right)$. The increase in $\mathrm{O}_{3}$ during the lockdown period is observed at Teynampet (48.01\%) and Velachery (5.16\%), but the Alandur site reported a decrease in $\mathrm{O}_{3}$ values $(33.37 \%)$ during the lockdown period.

- The CWT analysis reveals the change in source regions during lockdown for the transported pollution reaching to Chennai.

The present study supported the findings of previously published works on air pollution change during COVID-19 over Chennai, however, observe the variation separately for the different sites in the city. The study could able to find following crucial observations apart from previously reported work over Chennai: Higher $\mathrm{SO}_{2}$ values at Teynampet and Velachery with reduced $\mathrm{O}_{3}$ at Alandur and change in source region pattern during the lockdown period. Though the results are preliminary in nature and require further analysis to characterize the site specific variation over the region, it is evident that the average reduced values of air pollutants may not be able to satisfy the individual localities of a region during the COVID-19 lockdown.

\section{ADDITIONAL INFORMATION}

\section{Declaration of Competing Interest}

The authors declare that they have no known competing financial interests or personal relationships that could have appeared to influence the work reported in this paper.

\section{Conflict of Interest}

On behalf of all authors, the corresponding author states that there is no conflict of interest.

\section{ACKNOWLEDGEMENTS}

Authors want to acknowledge the Central Pollution Control Board (https://cpcb.nic.in), AirNow group (www.airnow.gov) and world air quality index (https://waqi.info/aqien.org) for providing the datasets. We want to thank HYSPLIT development team for providing the model and National Center for Environmental Prediction (NCEP) for the GDAS data. We are thankful to the Editor, Prof. Rajasekhar Balasubraman and two anonymous reviewers for their constructive suggestions to improve the quality of this manuscript. 


\section{REFERENCES}

Ahmadi, M., Sharifi, A., Dorosti, S., Ghoushchi, S.J., Ghanbari, N. (2020). Investigation of effective climatology parameters on COVID-19 outbreak in Iran. Sci. Total Environ. 729, 138705. https://doi.org/10.1016/j.scitotenv.2020.138705

Arora, S., Bhaukhandi, K.D., Mishra, P.K. (2020). Coronavirus lockdown helped the environment to bounce back. Sci. Total Environ. 742, 140573. https://doi.org/10.1016/j.scitotenv.2020.140573

Arshad, A., Hussain, S., Saleem, F., Shafeeque, M., Khan, S.N., Waqas, M.S. (2020). Unprecedented reduction in airborne aerosol particles and nitrogen dioxide level in response to COVID-19 pandemic lockdown over the Indo-Pak region. Earth and Space Science Open Archive. https://doi.org/10.1002/essoar.10503543.1

Arumugam, R., Rajathi, M. (2020). Air pollution during pre pandemic Covid-19 and in the lockdown period at Chennai city: A statistical study. Juni Khyat 10, 153-163.

Bao, R., Zhang, A. (2020). Does lockdown reduce air pollution? Evidence from 44 cities in northern China. Sci. Total Environ. 731, 139052. https://doi.org/10.1016/j.scitotenv.2020.139052

Bashir, M.F., Ma, B., Komal, B., Bashir, M.A., Tan, D., Bashir, M. (2020). Correlation between climate indicators and COVID-19 pandemic in New York, USA. Sci. Total Environ. 728, 138835. https://doi.org/10.1016/j.scitotenv.2020.138835

Bherwani, H., Nair, M., Musugu, K., Gautam, S., Gupta, A., Kapley, A., Kumar, R. (2020). Valuation of air pollution externalities: Comparative assessment of economic damage and emission reduction under COVID-19 lockdown. Air Qual. Atmos. Health 13, 683-694. https://doi.org/10. 1007/s11869-020-00845-3

Bontempi, E. (2020). First data analysis about possible COVID-19 virus airborne diffusion due to air particulate matter (PM): The case of Lombardy (Italy). Environ. Res. 186, 109639. https://doi.org/10.1016/j.envres.2020.109639

Census (2011). The Registrar General \& Census Commissioner, India. http://www.censusi ndia.gov.in/2011census/population_enumeration.html

Collivignarelli, M.C., Abbà, A., Bertanza, G., Pedrazzani, R., Ricciardi, P., Miino, M.C. (2020). Lockdown for CoViD-2019 in Milan: What are the effects on air quality? Sci. Total Environ. 732, 139280. https://doi.org/10.1016/j.scitotenv.2020.139280

Conticini, E., Frediani, B., Caro, D. (2020). Can atmospheric pollution be considered a co-factor in extremely high level of SARS-CoV-2 lethality in Northern Italy? Environ. Pollut. 261, 114465. https://doi.org/10.1016/j.envpol.2020.114465

CPCB (2015). Central Pollution Control Board report on National Air Quality Index. Series: CUPS/82/2014-15, p. 58.

Dantas, G., Siciliano, B., França, B.B., da Silva, C.M., Arbilla, G. (2020). The impact of COVID-19 partial lockdown on the air quality of the city of Rio de Janeiro, Brazil. Sci. Total Environ. 729, 139085. https://doi.org/10.1016/j.scitotenv.2020.139085

Dimitriou, K. (2015). The dependence of PM size distribution from meteorology and localregional contributions, in Valencia (Spain) - a CWT approach. Aerosol Air Qual. Res. 15, 19791989. https://doi.org/10.4209/aaqr.2015.03.0162

Draxler, R.R., Hess, G.D. (1998). An overview of the HYSPLIT_4 modelling system for trajectories. Australian Meteorol. Magazine 47, 295-308.

Fattorini, D., Regoli, F. (2020). Role of the chronic air pollution levels in the Covid-19 outbreak risk in Italy. Environ. Pollut. 264, 114732. https://doi.org/10.1016/j.envpol.2020.114732

Ghude, S.D., Pfister, G.G., Jena, C., Van Der A, R.J., Emmons, L.K., Kumar, R. (2013). Satellite constraints of nitrogen oxide $\left(\mathrm{NO}_{\mathrm{x}}\right.$ ) emissions from India based on OMI observations and WRFChem simulations. Geophys. Res. Lett. 40, 423-428. https://doi.org/10.1002/grl.50065

Guttikunda, S.K., Jawahar, P. (2018). Evaluation of particulate pollution and health impacts from planned expansion of coal-fired thermal power plants in India using WRF-CAMx modeling system. Aerosol Air Qual. Res. 18, 3187-3202. https://doi.org/10.4209/aaqr.2018.04.0134

Jain, S., Sharma, T. (2020). Social and travel lockdown impact considering coronavirus disease (COVID-19) on air quality in megacities of India: Present benefits, future challenges and way forward. Aerosol Air Qual. Res. 20, 1222-1236. https://doi.org/10.4209/aaqr.2020.04.0171

Kumar, P., Hama, S., Omidvarborna, H., Sharma, A., Sahani, J., Abhijith, K.V., Debele, S.E., Zavala- 
Reyes, J.C., Barwise, Y., Tiwari, A. (2020). Temporary reduction in fine particulate matter due to 'anthropogenic emissions switch-off' during COVID-19 lockdown in Indian cities. Sustainable Cities Soc. 62, 102382. https://doi.org/10.1016/j.scs.2020.102382

Laxmipriya, S., Narayanan, R.M. (2020). Seasonal variation in atmospheric particulate matter pollution-a comparative study in part of greater Chennai, India during and before SARS-Cov-2 pandemic in India. J. Xidian Univ. 14, 5957-5964. https://doi.org/10.37896/jxu14.5/645

Muhammad, S., Long, X., Salman, M. (2020). COVID-19 pandemic and environmental pollution: A blessing in disguise? Sci. Total Environ. 728, 138820. https://doi.org/10.1016/j.scitotenv.20 20.138820

Nakada, L.Y.K., Urban, R.C. (2020). COVID-19 pandemic: Impacts on the air quality during the partial lockdown in São Paulo state, Brazil. Sci. Total Environ. 730, 139087. https://doi.org/10. 1016/j.scitotenv.2020.139087

Navinya, C., Patidar, G., Phuleria, H.C. (2020). Examining effects of the COVID-19 national lockdown on ambient air quality across urban India. Aerosol Air Qual. Res. 20, 1759-1771. https://doi.org/10.4209/aaqr.2020.05.0256

Oke, T.R., Mills, G., Christen, A., Voogt, J.A. (2017). Urban climates. Cambridge University Press.

Paital, B. (2020). Nurture to nature via COVID-19, a self-regenerating environmental strategy of environment in global context. Sci. Total Environ. 729, 139088. https://doi.org/10.1016/j.scito tenv.2020.139088

Şahin, M. (2020). Impact of weather on COVID-19 pandemic in Turkey. Sci. Total Environ. 728 , 138810. https://doi.org/10.1016/j.scitotenv.2020.138810

Sahu, S.K., Beig, G., Sharma, C. (2008). Decadal growth of black carbon emissions in India. Geophys. Res. Lett. 35, L02807. https://doi.org/10.1029/2007GL032333

Sahu, S.K., Ohara, T., Beig, G. (2017). The role of coal technology in redefining India's climate change agents and other pollutants. Environ. Res. Lett. 12, 105006. https://doi.org/10.1088/ 1748-9326/aa814a

Sahu, S.K., Tyagi, B., Pradhan, C., Beig, G. (2019). Evaluating the variability, transport and periodicity of particulate matter over smart city Bhubaneswar, a tropical coastal station of eastern India. SN Appl. Sci. 1, 383. https://doi.org/10.1007/s42452-019-0427-2

Shahzad, F., Shahzad, U., Fareed, Z., Iqbal, N., Hashmi, S.H., Ahmad, F. (2020). Asymmetric nexus between temperature and COVID-19 in the top ten affected provinces of China: A current application of quantile-on-quantile approach. Sci. Total Environ. 736, 139115. https://doi.org/ 10.1016/j.scitotenv.2020.139115

Sharma, S., Zhang, M., Gao, J., Zhang, H., Kota, S.H. (2020). Effect of restricted emissions during COVID-19 on air quality in India. Sci. Total Environ. 728, 138878. https://doi.org/10.1016/j.sci totenv.2020.138878

Sicard, P., De Marco, A., Agathokleous, E., Feng, Z., Xu, X., Paoletti, E., Rodriguez, J.J.D., Calatayud, V. (2020). Amplified ozone pollution in cities during the COVID-19 lockdown. Sci. Total Environ. 735, 139542. https://doi.org/10.1016/j.scitotenv.2020.139542

Siddiqui, A., Halder, S., Chauhan, P., Kumar, P. (2020). COVID-19 pandemic and city-level nitrogen dioxide $\left(\mathrm{NO}_{2}\right)$ reduction for urban centres of India. J. Indian Soc. Remote Sens. 48, 999-1006. https://doi.org/10.1007/s12524-020-01130-7

Singh, R.P., Chauhan, A. (2020). Impact of lockdown on air quality in India during COVID-19 pandemic. Air Qual. Atmos. Health 13, 921-928. https://doi.org/10.1007/s11869-020-00863-1

Sinha, P.R., Sahu, L.K., Manchanda, R.K., Sheel, V., Deushi, M., Kajino, M., Schultz, M.G., Nagendra, N., Kumar, P., Trivedi, D.B., Koli, S.K. (2016). Transport of tropospheric and stratospheric ozone over India: Balloon-borne observations and modeling analysis. Atmos. Environ. 131, 228-242. https://doi.org/10.1016/j.atmosenv.2016.02.001

World Health Organization (WHO) (2020). Rolling updates on coronavirus disease (COVID-19). https://www.who.int/emergencies/diseases/novel-coronavirus-2019/events-as-they-happen (accessed on 21 July 2020).

Zhang, Z., Arshad, A., Zhang, C., Hussain, S., Li, W. (2020). Unprecedented temporary reduction in global air pollution associated with COVID-19 forced confinement: A continental and city scale analysis. Remote Sens. 12, 2420. https://doi.org/10.3390/rs12152420 